of antiquity which have been destroyed. Apart from the educational appeal of the buildings in their original relation, and so far as possible, in an appropriate setting, they will afford- the scholar a constant inspiration to further research, as well as provide a source of evidence for correcting or reconstructing theory in the light of later knowledge, such as never can be derived from a written record, photograph or drawing. The excavations now in progress may reinforce the argument, or should the City's decision be adverse to preservation, justify a delay, which will then be urged, pending an appeal for funds from outside sources for the complete excavation of the site in the coming year. The conflict between duty to local economies and the preservation of antiquities, which are national in their interest, is one which is likely to arise with increasing frequency in view of the rapid development of urban and suburban properties now taking place. When such developments affect relics of wide historic and scientific interest, as at Leicester, it is a question whether national funds should not be called on to assist.

\section{Potters of Lincoln}

MucH interest is attached to the discovery of a Roman potter's kiln at Lincoln, fully loaded with a light cream ware, and fired, but unopened. It affords evidence that an industry, which discoveries in 1932 have shown to have been in existence here in the Middle Ages, was also extensively practised in the Roman period. Quite possibly, as 'Pottergate Arch' nearby, and the occurrence of 'Pottergate' as a street name in the thirteenth century would suggest, the industry may have survived throughout the interval between medieval and Roman times with little or no interruption. The kiln was discovered, it is reported in The Times of August 21, on a site in Cathedral Street. It contained vessels of the mortaria type, the large shallow basins with a heavy rim, in which the Romans used to grind their food. The kiln was a hole in the ground four feet long and two feet wide, with a well-fired wall on two sides. It was roofed over with a whitish clay mixed with sand; and it contained four stacks of pottery, which had been considerably crushed. Curious short pipes, of which the use is obscure, were also found. Many of the vessels were stamped with the potter's mark, which, when deciphered, should afford a clue to the distribution of Lincoln pottery in Britain. The medieval pottery, which was found in this area, was attributed to the fourteenth century. No doubt the potters of that date drew their clay from the same source as their Roman predecessors. This in itself would be sufficient to account for the persistence of the industry in this area.

\section{Minoan Infiuences in Ancient Syria}

Sir Arthur Evans, commenting on the results of Sir Leonard Woolley's recent archæological investigations in Syria (see NATURE of July 4, p. 20 and August 8, p. 235), pronounces the Minoan impact on inner Syria at so early a date, for which the ceramic relics from Tell-Atchana afford evidence, as "a new historic fact of far reaching importance and revolutionizing all previous ideas". It is, he points out in The Times of August 19, a step forward of at least two centuries; for although there are no actual imports from Minoan Crete, the starting point in repeated examples of pottery reflecting Cretan models must certainly touch 1700 B.c. Sir Arthur bases this conclusion on the chronological datum of remains of cups, of somewhat thin make, showing white rosettes on a black ground, recalling the "egg-shell ware" bowls of the great age of Minoan Crete of the Second Middle Minoan period, which goes back to the eighteenth and nineteenth centuries, but in Syria equating with the succeeding Third Middle Minoan style. At the same time, mixed influence is to be seen in the combination of arcaded zones, characteristically Minoan, with highly conventionalized ducks, which find a parallel in early Palestine, while one of the sherds depicts an uprearing goat charged by another, whereas animal designs were excluded from the vase painting of Cretan Palace art. In concluding with an analysis of motifs, which point to a fusion of Cretan and indigenous religious and symbolic ideas, relating to the cult of the double axe, and reference to tradition of a royal alliance with Cyprus, Sir Arthur holds out the alluring possibility that the spade may yet uncover a royal sepulchre at Tell-Atchana.

\section{Special Exhibit at Ipswich Museum}

IN 1917, Mr. Reid Moir announced the discovery of flint implements, mammalian and human bones, and fragments of rough pottery, in the lower of two superposed 'floors' in a brickfield of Messrs. Bolton \& Co. at Ipswich. These occupation levels occurred in sand, and were overlain by a considerable thickness of hill-wash, while the excavations carried out showed that the now dry valley in which the discoveries were made has been deepened by erosion since the floors were occupied by man. Similar results were obtained, at a later date, by Mr. J. P. T. Burchell, in his researches at Ingress Vale in the lower Thames Valley. Here, at the base of an extensive section of sub-aerial loam, surmounted by a hill-wash containing rafts of Coombe Rock, was found a prolific floor, with flint implements, flakes, and fragments of primitive pottery. The third site, where a similar association of relics occurred, was discovered and investigated by $\mathrm{Mr}$. and Mrs. MacAlpine Woods in a dry valley at Bovey Lane, Beer, Devon. In this case, a hill-wash, some $11 \mathrm{ft}$. in thickness, contained large numbers of flint artefacts, a few examples of bones and teeth of animals, and some pieces of rough pottexy. Through the kindness of the discoverers, the Ipswich Museum now possesses representative series of the specimens mentioned, and is making a special exhibition of them. The matter is of considerable interest to archæologists as, in each case, the flint implements may be said to resemble, in their forms, those of Lower and Upper Aurignacian times, and are not associated with any microliths. Moreover, there seems good reason to believe that the widespread deposits in which the relics were embedded 